\title{
Human Resource Development and Utilization: A Tool for National Economic Growth
}

\author{
Musa Sabo Abdullahi \\ Federal College of Education, \\ Kontagora, Niger State,Nigeria
}

\section{Doi:10.5901/mjss.2013.v4n8p153}

\begin{abstract}
Economic development of the nation is the major preoccupation of most governments of the developed, developing and third world countries. As such, human resource has been identified as one of the most important wheel driver in a nation's development. Infact it is the major propeller for development. In Nigeria, this important and critical resource has not been fully developed, managed and utilized in such a manner that would make the country achieve economic growth and development. The paper attempts to discuss some factors that if addressed will bring about economic growth and developmental goals. Some of these factors include adequate budgetary allocation to education sector, human resource development and training, entrepreneurship development, corruption, provision of social amenities and eradication of poverty among Nigerian population. Thus, the paper made some recommendations among which are the need for a more focused responsive, functional and qualitative educational system; to contribute significantly to economic growth and development, education must be of high quality and also meet the skill-demand needs of the economy and government must fight corruption in its totality because it is the endemic disease that has pervaded the nation.
\end{abstract}

Keywords: Human resource, development, utilization, national economic, growth

\section{Introduction}

The Nigerian economy could be said to have enjoyed some form of macroeconomic stability in the recent period as the rate of economic growth averaged 2.01 percent within the last two to three decades. However, as a result of rapid population growth rate, per capita growth has remained negative and it averaged -0.852 (World Development Indicator, 2004). With its large reserves and continued production of both human and natural resources, Nigeria has the potential to build a prosperous economy, reduce poverty significantly, and provide health, education, and infrastructural services that its population needs (Abdullahi and Kim, 2011). This will in turn provide the much needed national security.

Nevertheless, despite the country's relative oil wealth, poverty is widespread (oil revenue is only about $.50 \mathrm{c}$ per capita), and Nigeria's basic social indicators place it among the twenty poorest countries in the world (World Bank, 2004). Poverty, which has no geographical boundary, is seen in all part of the country, rural and urban areas inclusive. Although the incidence of poverty is much higher in the rural areas than in the urban centres, the urban slum-dwellers form one of the more deprived groups in Nigeria. The poor are those who are unable to obtain an adequate income, find a stable job, own property or maintain healthy living conditions. They also lack an adequate level of education and cannot satisfy their basic health needs. As such the poor are often illiterate, in poor health and have a short life span (Abdullahi and Kim, 2011). The attempt by Nigeria to shift the focus of the economy from the oil industry to other economic activities has been unsuccessful, largely due to corruption, low investment, and a largely unskilled labour force. The education that most Nigerians receive is not very good. Children attend primary schools which last for six years, but the education they receive there is not sufficient. 
However, it is still very important for Nigeria to increase the growth rate in other sectors of the economy. A good way of generating economic growth is through educational development. The basic importance of education is to enable individuals acquire knowledge and the ability to apply that knowledge. Education is therefore commonly regarded as the most direct avenue to rescue a substantial number of people out of poverty since there is likely to be more employment opportunities and higher wages for skilled workers. Furthermore, education can enhance children's attitudes and assist them to grow up with social values that are more beneficial to the nation and themselves. It is commonly assumed that education has an important positive effect on economic growth, but to date the evidence for this assumption has been surprisingly weak and fast fading.

\section{Education and Entrepreneurship}

Education at all levels contributes to economic growth through imparting general attitudes and discipline and specific skills necessary for a variety of workplaces. It contributes to economic growth by improving health, reducing fertility and possibly by contributing to political stability. However, education has been an instrument toward the development of human resources in Nigeria. The major importance of the educational system to any labour market would depend mainly in its ability to produce a literate, disciplined, flexible labour force via high quality education. Consequently, with economic development new technology is applied to production, which results in an increase in the demand for workers and better education (Musibau and Rasak, 2005).

Education is obviously the basic instrument of economic growth and technological advancement in any society. It is in recognition of this fact that governments commit immense resources to ensure the provision of education for their citizens, and also tailor their policies towards ensuring that it is made accessible to the generality of their citizenry (Ukertor, 2010). However, government policies on education in Nigeria have never been adequately implemented to succeed. This could be as a result of corruption, poor implementation of programmes and many other factors as earlier noted above.

There is no gain-saying the fact that many Nigerians obtain degrees, diplomas and certificates in disciplines not particularly required by the economy, and invariably end up without jobs or with jobs not related to their academic training. This reduces the efficiency of the educational system. There is, therefore, the need to make the system more relevant to the development of the human resources. This is required for the nation's development. The task of national development is enormous and should not be the exclusive responsibility of the government. Furthermore, the development of the nation's universities for human resources development should be a joint responsibility: of the government at all levels, professional organisations, religious organisations, alumni, communities, industrial organisations, individuals, and the educational institutions through their management efforts.

Perhaps, the use of education to develop the human resources of Nigeria might be the roadmap to the attainment of economic development. This might require huge budgetary consideration and investments in education for occupational preparation that will qualify them to be self employed and reduce the labour market, thereby promoting economic growth. This can be assured when quality technical education is provided for the nation to enable its citizenry.

The development of a nation relies on the development and capability of human resource (manpower) of the nation. Therefore, the effort to push Nigeria forward to attain the desired economic growth depends on the quantum and magnitude of its manpower skills and the level of economy of the nation. To achieve this goal, Nigeria will need to enhance her socio-economic and political development performance in order to develop the manpower requirement which may be based on certain parameters as observed by Peters (2009):

- A peaceful, harmonious and a stable democracy;

- A sound, stable and globally competitive economic;

- Adequate infrastructure service that support the full mobilization of all economic sectors; 
- Modern and vibrant education system which provides for every Nigerian the opportunity and facility to achieve his/her maximum potential and provides the country with adequate and competent manpower;

- A health sector that supports and sustains a life expectancy of not less than 70 years and reduces to the barest minimum the burden of infectious diseases such as malaria, HIVIAIDS and other debilitating diseases.

- A modern technologically enabled agricultural sector that fully exploits the vast agricultural resources of the country;

- Ensure national food security and contributes significantly to foreign exchange earnings; and

- Vibrant and globally competitive manufacturing sector that contributes significantly to Gross Domestic Product (GDP) with a manufacturing value added.

As defined by the European Commission, "Entrepreneurship refers to an individual's ability to turn ideas into action. It includes creativity, innovation and risk taking, as well as the ability to plan and manage projects in order to achieve objectives (Jean-pierre \& Gariel, 2009). It is generally agreed that entrepreneurial behaviour remains a crucial engine of innovation and growth for the national economy and for individual companies.

Entrepreneurship is an important facet of industrial growth and the backbone of any country's economic development. The spirit of entrepreneurship brings about enthusiasm, persistence and the ability to seek entrepreneurial opportunities that lead to success. A country's ability to generate a steady stream of business opportunities can only come about when its people take to entrepreneurial activities. Entrepreneurs are essentially the engines of growth for a country (Abdullahi and Abdullahi, 2011).

As defined by the European Commission, "Entrepreneurship refers to an individual's ability to turn ideas into action. It includes creativity, innovation and risk taking, as well as the ability to plan and manage projects in order to achieve objectives (Jean-pierre \& Gariel, 2009). If Entrepreneurs are essentially the engines of growth for a country, and in recognition of this potential, as well as a realisation that more needs to be done in order to achieve it, the Ministry of Education in conjunction with tertiary institutions should as a matter of urgency and concern establish entrepreneurship training centres across all the tertiary institutions across the country in order to either train or retrain our teeming unemployed youth across the country towards self employment and dependence on government jobs will certainly reduce.

This is because Entrepreneurs are individuals who are continually looking for opportunities to start/grow their own businesses, while entrepreneurship skills include leadership, creativity, marketing/sales, negotiation, administration, time management, self-motivation, financial management and a range of interpersonal skills. Entrepreneurship in the broadest sense is defined as "an activity which leads to the creation and management of a new organisation design to pursue a unique, innovative opportunity" (Clark, 2004). He corroborated Plato's idea on entrepreneurship as:

Do not train a child to learn by force or harshness but direct them to it by what amuses their minds, so that you may be better able to discover with accuracy the peculiar bent of the genius of each. Plato, 428BC(in Marilyn \& Gaynor, 2006)

\section{Human Resource Development}

According to Miachi (2006), historical evidences proved that advanced countries depended on education for their rapid economic growth, such as those of United States, former Soviet Union, Denmark and Japan. There were significant relationships between their economic growth and the quantum and kinds of education provided to their work-forces. Harbison and Myers (1964) found a significant Statistical relationship between levels of human capital development and the levels of Gross National Product (GNP). Human resources of a nation refer to the totality of population of a country, which determines the potential labour force of a nation. 
Investment in the human resource determines the type, quality, availability and productivity of the nation's manpower and it involves the socio-economic development strategies (European Commission, 2007).

The giant strides of Nigeria's vision 20:2020 were attempts to improve the standard of living of its citizenry by effective generation of wealth and reduction of poverty. Efforts to achieve the goal were subjected to education by reform of policies which are conscious efforts, and direct means of developing the full potentials and capacities of the human resources to move along with the tide of change across the world.

However, the Nigerian education system is unable to produce the required manpower requirement needs of the various sectors of the economy. The imbalance between the products of education and the labour market needs becomes a mirage in the nation. Consequently, unemployment has become a social problem affecting the nation. This might have arisen from educational plans which are often made without accurate data coupled with the low economy of Nigeria to adequately train the huge human resources of the nation (Gyang, 2011). It is a fact that the higher the economy of the nation the higher the quality of human resources to be trained and the higher skilful manpower produced will in turn produce wealth from the labour market and can raise the economy of the nation. Therefore, financing education effectively becomes a determinant factor for human capital investment towards economic development of the nation to achieve vision. The clear and realistic paths to human resources development for economic growth requires that immediate and useful action be taken to improve the quality of the educational system in order to obtain quality manpower for the nation's economy growth and development.

\section{Human Resource Training}

Human Resource Development (HRD) is the framework for helping employees to develop their personal and organizational skills, knowledge, and abilities. Human Resource Development includes such opportunities as employee training, employee career development, performance management and development, coaching, mentoring, succession planning, key employee identification, tuition assistance, and organization development.

Human resource training and developing programmes may be broadly classified into two. These are off-the-job training and on-the-job training. Off-the-job training refers to all training one has acquired before taking up the employment such as primary education, secondary education, training from universities and colleges, professional training, apprenticeship, attendance of lectures and conferences and the likes. On-thejob training may be referred to training received, during one's career but outside his place of work, i.e. inservice training. Examples are special courses, conferences, lectures, seminars and symposia which are not directly organized for the employee by his organization. Of particular reference is an employee attaining higher qualifications (degree and professional certificates) outside his workplace. On the other hand, on-thejob training encompasses all training received in the course of one's employment and at the place of work. Such training includes job rotation, employee transfer and secondment, promotion, understudy and even induction training. There are also specifically organized briefing, symposia, and lectures etc that take place at the workplace.

It has become a song in the mouth of human resource experts in the country and more serious nations of the world that no nation develops more than its human capital. For this reason, countries all over the world invest a large portion of their budget on education. To these experts and the countries, the Alpha and Omega of any development in any country is 'man' and when any state ignores its human capital development it would remain undeveloped (Kenneth, 2009).

Apparently, the key to effective manpower development (education and training) and utilization (employment) is planning. Manpower planning is the process by which a nation ensures that it has the right kind of people at the right place and at the right time, and who are doing things for which they are economically most useful. It requires taking stock of the present manpower resources in terms of potential performance considering the working population, and determining the future demand for manpower. 
Manpower planning is undertaken to enable a nation discover per time, the critical skills in the labour force where shortages are most likely to develop or where there is inefficient use of labour (Miachi, 2006). Manpower availability is a precondition and a prime test of feasibility of an economic plan and because the goal of economic planning is to improve the lot of the man himself. Manpower development of a nation requires the improvement of the economy through the use of educational programmes, the in-service training of workers and the provision of incentives to get people into critical or productive economic sectors and occupations that will make Nigeria achieve human resource development for economic growth.

\section{Nigeria's Economic Potentials}

Nigeria's economic potential has never been in doubt. The country is greatly endowed with abundant human and natural resources, which, if properly harnessed, should catapult us into the big league. But 52 years after independence, very little of this potential has been realized. Development commentators have often blamed this state of affairs on poor vision and planning by successive administrations. Others have pointed a finger at poor synergy between developmental efforts at the national and state levels (Benedict, 2009). Nigeria is enormously endowed with so much natural resources that have never been tapped or located in different parts of the country. Many of these natural sites are either being illegally tapped or are not given attention for political reasons. Agriculture that had been the main stay of the economy in the 1960s when we used to have groundnuts and cotton pyramid, hide and skin in the north, cocoa and rubber in the west before the discovery of oil in the south east, and all these contributed substantially to the economic growth of the country. However, the situation changed when government abandoned agriculture and diverted to oil as its source of revenue. Now many alternative source of energy have and more are being discovered to the disadvantage of the use of oil world wide. But the Nigerian government is yet to pay more attention to some of these natural resources to assist the weak economy and create more job opportunities for the teeming unemployed youth which is rising above $20.3 \mathrm{~m}$ about $21 \%$ (Nangak, 2013). The economic potentials of the country can maximally be realized if agriculture, our mineral natural resources, power supply, etc. are given the desired policy attention.

\section{Corruption}

Corruption may be found everywhere, however its pervasiveness in Nigeria is sometimes referred to as the "Nigerian factor" by Nigerian themselves. The Central Bank Governor Sanusi Lamido says culture impunity is much more than corruption has hampered Nigeria's development and promoted poverty. He noted that corruption is a universal problem, but added that that of other countries were able to attain development because they had adequate punitive structures in place. According to him, corruption is a big issue in the country today as in other parts of the world, like Russia, China and others, but why are they eradicating poverty and Nigeria is not? It is not just corruption. It is the kind of failed interventions that are procured with the proceeds of corruption. We know that everyone agree that corruption is bad. It has economic cost. Sanusi however, said although the country had achieved certain macro-economic improvements, poverty is still high because certain fundamentals such as infrastructures were not in place. He however added that as soon as those fundamentals are in place Nigerians will begin to benefit from the macro-economic stability (Sanusi, 2013).

Political corruption is the use of power by government officials for illegitimate private gain. Misuse of government power for other purposes, such as repression of political opponents and general police brutality, is not considered political corruption. Neither are illegal acts by private persons or corporations not directly involved with the government. An illegal act by an officeholder constitutes political corruption only if the act is directly related to their official duties, is done under color of law or involves trading in influence. Forms of corruption vary, but include bribery, extortion, cronyism, nepotism, patronage, graft, and embezzlement. 
Corruption may facilitate criminal enterprise such as drug trafficking, money laundering, and human trafficking, though is not restricted to these activities. The activities that constitute illegal corruption differ depending on the country or jurisdiction. For instance, some political funding practices that are legal in one place may be illegal in another (Wikipedia, 2013). Similarly, corruption is widely favoured by conditions such as information deficits, lacking control of the government, opportunities and incentives and social conditions.

\section{Recommendations}

Nigeria is confronted by a number of problems that could limit the capacity of expansion in education to stimulate growth and development such as corruption, unemployment, low absorptive capacity, and shortage of professionals, regional imbalances and brain-drain. The persistence of many of the problems in spite of the various policy formulation and responses points to the need for a more focused responsive, functional and qualitative educational system. To contribute significantly to economic growth and development, education must be of high quality and also meet the skill-demand needs of the economy. It is not a noble achievement for any sector of the economy to exist for years only to make a negligible contribution to economic growth, which is not commensurate with its life span and investment.

Similarly, government must as matter of urgency generate and provide electricity, portable water supply, adequate shelter, qualitative and entrepreneurial skills to unemployed, enlightenment programmes through electronic and print media. For government to achieve these objectives, the issue of corruption must be tackled in its totality.

\section{Conclusion}

With its large reserves and continued production of both human and natural resources, Nigeria has the potential to build a prosperous economy, reduce poverty significantly, and provide health, education, and infrastructural services that its population needs. Nigeria as a developing country can develop its human and natural resources to realize aspiration of the citizenry if education sector can be given adequate budgetary consideration, economic potentials of the country be tapped and utilized, human resources training be enhanced to meet the requirement of the economy, political corruption, many social amenities (potable water supply, health care, infrastructures, etc.) are put in place, entrepreneurship training is improved and instituted in all tertiary institutions and structures to eradicate the endemic corruption are in place, Nigeria can compete favourably with the developed countries world over. Recommendations were also made.

\section{References}

Abdullahi, M. S. and Abdullahi, I. B. (2011): Equipping the Youths with Entrepreneurship Skills through Educational Policy and Initiatives for National Development. Nigerian Journal of Science and Educational Research in Association with the Association of Science Educators of Nigeria. 7(2): 74-79..

Abdullahi, M. S. and Kim, B. C. (2001): Human Resources Development: A key to Sustainability of Qualitative Education for the Growing Nigerian Population. A paper presented at the $8^{\text {th }}$ National Conference of the School of Sciences, held at the New Auditorium, Federal College of Education, Kontagora, Nigeria. From 26 ${ }^{\text {th }}-30^{\text {th }}$ September, 2011.

Benedict, I. (2009): Nigeria Vision 20: 2020: The Future of Akwa Ibom. News Paper Article. The News. 26th Sept. 2009.

Clark, B. R. (2004). Sustaining Change in Universities: Continuities in case studies and concepts. Berkshire, England: Open University Press.

European Commission (2007): Enterprise and industry directorate-general. Europe: Brussels, Europe.

Harbison, F. H. and Myers, C. A. (1964). Education, manpower and economic growth; Strategies of Human development. London: McGraw Hill.

Jean-Pierre, M. \& Gabriel, M. F. C. (2009). Developing Entrepreneurship in Europe: Best Practices and Innovative Ideas. A ComplexEIT contribution. Workshop: $11^{\text {th }}$ June 2009, Strasbourg.

Kenneth, M. (2009): Human Capital Development Crucial to Vision 20 - 2020. Business News. 
Miachi, T. A. (2006). A systemic approach to human resources development and utilization: A sectorale analysis. A lead discussion paper at the interactive session with the senior Executive Course No.28, of the National Institute for Policy and Strategic Studies (NIPSS) Kuru, Jos.

Musibau, A. B. \& Rasak, A. A. (2005). Long Run Relationship between Education and Economic Growth in Nigeria: Evidence from the Johansen's Cointegration Approach. Paper presented at the Regional Conference on Education in West Africa: Constraints and Opportunities Dakar, Senegal, November 1st - 2nd, 2005. Cornell University I CREA / Ministèrede l'Education du Sénégal.

Nenkag, D. G. (2013): How to cure Unemployment in Nigeria. Youthhub Africa.

Peters, A. A. (2009). Human capital requirement for good governance and the realization of vision 20:2020 and the seven point agenda. Paper delivered to the

Participants of senior executive course No.31 at the National Institute of Strategic Studies, Kuru, Jos, Plateau State on Tuesday, 5th may, 2009.

Plato (428BC). In Marilyn, W. \& Gaynor, R.(2006). The Role of Higher and Further Education. Department for Culture, Media and Sport Creative Industries Entrepreneurship Task Group. London. SW1Y SDH. May 2006.

Sanusi, L. (2013): Impunity, not Corruption is Nigeria's Biggest Problem. Vanguard. The News. 29th March, 2013.

Ukertor, G. M. (2010). "The Challenges of Access to University Education in Nigeria". DSM Business Review Vol. 2, No. 2 (December, 2010)

Wikipedia (2013): Political Corruption. The free encyclopaedia.

World Bank (2004), World Development Indicators 2004 on CD-ROM, World Bank, Washington D.C. 
